\title{
Regulation of the $\alpha$-Galactosidase Activity in Streptococcus pneumoniae: Characterization of the Raffinose Utilization System
}

\author{
Carsten Rosenow, ${ }^{1}$ Mita Maniar, and Joaquim Trias \\ Versicor, Inc., Fremont, California 94555 USA
}

\begin{abstract}
A 10.2-kb gene region was identified in the Streptococcus pneumoniae genome sequence that contains eight genes involved in regulation and metabolism of raffinose. The genes rafR and rafS are transcribed as one operon, and their gene products regulate the raffinose-dependent stimulation of a divergently transcribed second promoter $\left(P_{A}\right)$ directing the expression of aga, the structural gene for $\alpha$-galactosidase. Raffinose-mediated transcription from $P_{A}$ results in a 500-fold increase in $\alpha$-galactosidase activity in the cell. A third promoter within the cluster is responsible for the transcription of the remaining five genes (rafE, rafF, rafG, gtfA, and rafX), whose gene products might be involved in transport and metabolism of raffinose. The presence of additional internal promoters cannot be excluded. The aga promoter $P_{A}$ is negatively regulated by the presence of sucrose in the growth medium. Consistent with catabolite repression (CR), a DNA sequence with high homology to the CRE (cis-active element) was identified upstream of the aga promoter. Sucrose-mediated CR depends on the phosphoenolpyruvate: sucrose phosphotransferase system (PTS) but is unaffected by a mutation in a gene encoding a homolog of the CRE regulatory protein CcpA.
\end{abstract}

Streptococcus pneumoniae is limited in its sugar fermentation ability, being able to use fructose, galactose, sucrose, glucose, raffinose, lactose, inulin, threhalose, and maltose as sources of energy (Holt et al. 1994). The only characterized sugar transport system in S. pneumoniae is the maltodextrin (Mal) utilization system (Stassi et al. 1982). The mal operon has two negatively regulated promoters, both of which are only activated in the presence of maltose, maltotriose, or maltotetraose (Nieto et al. 1997). Little is known about the mechanism for the utilization of other sugars by $S$. pneumoniae. In contrast, carbohydrate utilization by Streptococcus mutans is well studied (Vadeboncoeur and Pelletier 1997). In S. mutans, sugar metabolism contributes to the initiation and progression of dental caries and is an important virulence determinant (Cvitkovitch et al. 1995). A well-characterized sugar utilization system in $S$. mutans is the multiple-sugar metabolism operon ( $m s m$ ) (Russell et al. 1992). This gene cluster contains eight genes, products of which are involved in the uptake of melibiose, raffinose, and isomaltotriose and the metabolism of melibiose, sucrose, and isomaltosaccharides. The cluster also contains the gene for a regulatory protein that acts as a positive effector.

The phosphoenolpyruvate: sugar phosphotransferase system (PTS) is one of the preferred carbohydrate uptake systems in bacteria. The PTS is a complex enzyme system that is responsible for the detection, transmembrane transport, and phosphorylation of nu-

'Corresponding author.

E-MAIL carsten_rosenow@affymetrix.com; FAX (408) 481-0422. merous sugar substrates in both Gram-negative and Gram-positive prokaryotes (Postma and Lengeler 1985). The PTS in bacteria is involved in the regulation of other, non-PTS carbohydrate uptake systems. This regulation is triggered by the presence of a preferred carbon source in the growth medium that inhibits the expression of proteins involved in the utilization of alternative carbon sources (catabolite repression) (Postma et al. 1993; Saier 1996). Catabolite repression in Gram-positive organisms can be controlled by the binding of the catabolite control protein (CcpA) to CREs (cis-acting element), a 14-bp region of dyad symmetry that has been identified upstream of genes under CcpA regulation (Hueck et al. 1994; Saier et al. 1996). Such regulatory mechanisms provide bacteria with the ability to select their preferred carbon and energy source from the environment by switching off genes that code for transport and metabolizing enzymes of other PTS and non-PTS systems. In many Gram-positive bacteria, glucose has been shown to repress synthesis of both PTS and non-PTS carbohydrate catabolic enzymes. This function of glucose in catabolite repression is linked to its role as the preferred carbon source in many bacteria (Saier et al. 1996).

We have identified in the $S$. pneumoniae genome a gene cluster that is involved in raffinose metabolism. Some of the genes show homology to genes of the $S$. mutans msm gene cluster. The $S$. pneumoniae gene cluster includes genes encoding $\alpha$-galactosidase $(a g a)$, an activator (rafR) and repressor ( $r a f S$ ) for aga expression, and genes whose products are homologous to sugar transport systems in other prokaryotes. The expression 
of $a g a$ is induced in the presence of raffinose and repressed in the presence of sucrose in the growth medium. The newly identified gene cluster enables $S$. pneumoniae to use raffinose as a carbon source. We demonstrate by insertional gene inactivation that in $S$. pneumoniae the sucrose-specific PTS, but not a CcpA homolog, is required for sucrose repression of aga.

\section{RESULTS}

\section{Gene Identification and Analysis}

Figure 1 shows the gene cluster retrieved from the partial genomic sequence database of $S$. pneumoniae (www.tigr.com). Some members of this gene cluster show high homology to members of the multiple-sugar metabolism cluster ( $\mathrm{msm}$ ) from $S$. mutans. The region containing the rafS, rafR, aga, and rafE genes was PCRamplified, using the high-fidelity DNA polymerase $P f u$, and sequenced. There was a difference of 12 nucleotide substitutions between the PCR-amplified sequence and The Institute for Genomic Research (TIGR) database that resulted in changes in protein sequence. In all but one case, the amino acid replacements were conservative. The sole exception was the change of Gly to Asp at residue 430 of the aga gene product.

The sequence similarities between the genes of the identified cluster to those of the msm system from $S$. mutans suggest that the pneumococcal gene products could be involved in transport and metabolism of $\alpha$-galactosides and/or other carbon sources. The $\operatorname{dex} B$ gene (dextran glucosidase) and the $m s m K$ gene (ATPbinding protein), both present in the $m s m$ cluster, are absent in the pneumococcal gene cluster. Two genes, rafS and raf $X$, are only found in the pneumococcal gene cluster.

Comparison of the RafS amino acid sequence with proteins in the public database revealed 34\% identity and $52 \%$ similarity to BirA from Bacillus subtilis, a bifunctional protein involved in biotin-operon repression and biotin-protein ligation (Bower et al. 1995). The amino acid sequence of RafR shows $40 \%$ identity and $60 \%$ similarity to the MsmR protein from $S$. $m u$ tans and contains a sequence signature (RMHRARQLLENTQESIKVIAYSVGFSDPLHFSKAYKQYFNQTP) of the AraC/XylS family of transcriptional regulators
(Russell et al. 1992; Gallegos et al. 1997). Aga is transcribed divergently from rafS and rafR and encodes a protein with $64 \%$ identity and $79 \%$ similarity to $\alpha$-galactosidase from $S$. mutans.

There is a noncoding region of $91 \mathrm{bp}$ between the termination codon of $a g a$ and the initiation codon of the rafE gene. The putative translational start codon (ATG) of rafE is preceded by a sequence with homology to a ribosome binding site and the promoter consensus sequence from S. pneumoniae (Sabelnikov et al. 1995) (Fig. 2B). The rafE gene encodes a protein with high homology to the $S$. mutans MsmE protein and other sugar binding proteins. A PROSITE search (GCG; Wisconsin Package) using the RafE sequence revealed the peptide sequence Arg-Gly-Asp (263-RGD-265) within RafE. This sequence has been shown to play a role in cell adhesion in various systems (Ruoslahti and Pierschbacher 1986; d'Souza et al. 1991) but its relevance in RafE is not known. In addition, the RafE sequence contains the ATP/GTP-binding site motif A (P-loop) (22ACSNYGKS-29). This sequence is known to interact with one of the phosphate groups of the nucleotide and is present in ABC transporters (Higgins et al. 1990). The third identified motif (138-PFTANAYGIYYNKDKFEE-155) is present in the family of bacterial extracellular solute-binding proteins (Tam and Saier 1993). The first 20 amino acids of the RafE protein specify a potential signal peptide, with a cleavage site (19-GlyLeu-Gly-Ala-Cys-Ser-25) similar to the bacterial lipoprotein consensus sequence (Leu-Ala-Gly/Ala-Cys) (von Heijne 1998).

The amino acid sequences of RafF and RafG are homologous of the corresponding Msm proteins, which are involved in sugar transport in $S$. mutans (Russell et al. 1992). Based on homology studies, GtfA could be a sucrose phosphorylase, which cleaves sucrose into fructose and glucose and phosphorylates the glucose for further metabolization (Russell et al. 1988). The last ORF in the cluster, rafX, encodes a protein with no significant homology to any known protein in the SWISS-PROT database and no motifs were identified using the PROSITE search.

Induction of the aga Promoter by Raffinose

The $\alpha$-galactosidase encoded by the aga gene was used

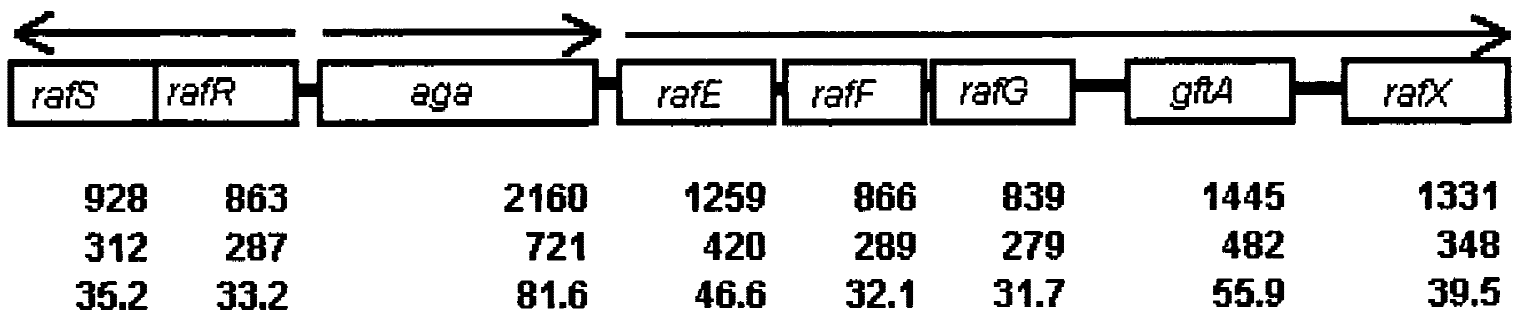

$\begin{array}{rrrrrrrrr}\text { bp } & 928 & 863 & 2160 & 1259 & 866 & 839 & 1445 & 1331 \\ \text { aa } & 312 & 287 & 721 & 420 & 289 & 279 & 482 & 348 \\ \text { Mr } & \mathbf{3 5 . 2} & \mathbf{3 3 . 2} & 81.6 & \mathbf{4 6 . 6} & \mathbf{3 2 . 1} & \mathbf{3 1 . 7} & \mathbf{5 5 . 9} & \mathbf{3 9 . 5}\end{array}$

Figure 1 Map of the raf genes in the S. pneumoniae contig. Arrows indicate operons and the orientation of transcription. The number of base pairs (bp), amino acids (aa), and the molecular mass $\left(M_{r}\right)$ of the corresponding proteins are indicated. 
A

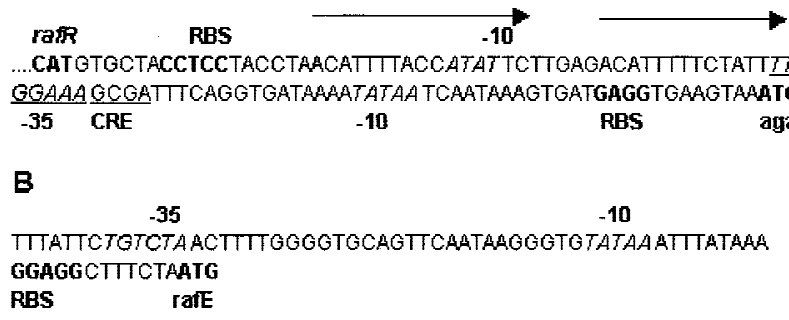

Figure 2 Sequence analysis of the intergenic region between rafR and aga $(A)$ and aga and $\operatorname{rafE}(B)$. Potential ribosome binding sites (RBS), -10 and -35 promoter elements (italics), and the direct repeats (arrows) are indicated. A 15-bp sequence with homology to the CRE consensus sequence is underlined.

as a reporter protein to analyze the regulation of its promoter $\left(P_{A}\right)$. Aga activity is measured in the cell lysate using a colorimetic assay with the substrate $p$-nitrophenyl- $\alpha$-D-galactopyranoside.

Very low $\alpha$-galactosidase activity $(0.4 \mathrm{U} / \mathrm{mg}$ of protein) could be detected in cell lysates of $S$. pneumoniae grown in semidefined medium $(\mathrm{C}+\mathrm{Y})$ in which glucose and sucrose are the only carbon sources. A 500-fold increase in activity was observed when sucrose and glucose in the growth medium were replaced by the $\alpha$-galactoside sugar raffinose [ $\alpha$-galactosyl (1-6) $\alpha$-glucosyl (1-2) $\beta$-fructose] at a concentration of $0.2 \%$ (wt/vol) (Table 1$)$. Another $\alpha$-galactoside sugar, melibiose [ $\alpha$-galactosyl (1-6) $\alpha$-glucosyl], does not support growth of pneumococcus when provided as the sole carbon source. In the presence of glucose, melibiose did not induce $\alpha$-galactosidase activity (data not shown). None of the other sugars tested (glucose, fructose, sucrose, galactose, lactose, maltose, inulin, and trehalose) induced $\alpha$-galactosidase activity, suggesting that raffinose is the only sugar capable of inducing aga expression (Table 1).

To determine the correlation between $\alpha$-galactosidase expression and raffinose concentration in the medium, pneumococcus strain R6x was grown in $\mathrm{C}+\mathrm{Y}$ medium supplemented with $0.2 \%$ glucose and different concentrations of raffinose. After $3 \mathrm{hr}$ of incubation, the $\alpha$-galactosidase activity in the cell lysate was measured. As shown in Figure 3, $\alpha$-galactosidase activity is dependent on the raffinose concentration in the medium and increases with higher raffinose concentrations up to saturation at $200 \pm 23 \mathrm{U} / \mathrm{mg}$ of protein at a raffinose concentration of $0.03 \%$ (wt/vol) in the medium.

\section{Regulation of the aga Promoter by RafR and RafS}

The homology of RafR to MsmR and other regulatory proteins within the AraC/XylS family of transcriptional regulators suggested that aga might be positively regulated by rafR. A rafR mutant showed only an 80fold increase in $\alpha$-galactosidase activity after induction with raffinose, compared with a 500-fold increase in the wild type strain (Table 1).

Similarly, homology of the RafS protein to the biotin repressor protein suggested a regulatory function for RafS. Insertional inactivation of the gene resulted in a mutant with 2.2-fold higher $\alpha$-galactosidase activity than the wild-type strain when both were grown in the presence of the inducer raffinose (Table 1).

To define the aga promoter by heterogeneous expression in Escherichia coli, a PCR fragment extending from the translational stop codon of rafR through the transcriptional start codon of rafE was amplified and cloned into pR326 (Claverys et al. 1995) resulting in plasmid pR326aga. The 2-kb amplified fragment was expected to include the aga gene as well as the extended aga promoter region necessary for aga regulation. E. coli harboring the plasmid pR326aga showed high levels of $\alpha$-galactosidase activity (Table 1 ). Introduction of a compatible plasmid carrying the rafR gene (including the putative promoter) into the same $E$. coli strain resulted in a fivefold increase in $\alpha$-galactosidase activity (Table 1). The endogenous levels of $\alpha$-galactosidase activity in $E$. coli were negligible.

\section{Specificity of the raf Cluster}

Mutants in each of the remaining genes (aga, rafE, rafF, rafG, gtfA, and rafX) were constructed by insertionduplication mutagenesis (see Methods). These strains and the parent strain were compared in their ability to ferment raffinose, trehalose, fructose, lactose, inulin,

\begin{tabular}{|c|c|c|}
\hline Strain ${ }^{a}$ & Carbon source & $\begin{array}{c}\alpha-G \text { alactosidase } \\
\text { activity } \\
\text { (U/mg protein) }^{b}\end{array}$ \\
\hline \multirow[t]{4}{*}{ sp. R6x (wild type) } & glucose & $0.7 \pm 0.1$ \\
\hline & glucose/sucrose & $0.4 \pm 0.1$ \\
\hline & glucose/raffinose & $200 \pm 40$ \\
\hline & sucrose/raffinose & $0.7 \pm 0.2$ \\
\hline \multirow[t]{3}{*}{ sp. R6x ( $\Delta p t s / l)$} & glucose & $0.8 \pm 0.1$ \\
\hline & glucose/raffinose & $220 \pm 38$ \\
\hline & sucrose/raffinose & $203 \pm 45$ \\
\hline \multirow[t]{3}{*}{ sp. R6x $(\Delta c c p A)$} & glucose & $0.7 \pm 0.1$ \\
\hline & glucose/raffinose & $238 \pm 44$ \\
\hline & sucrose/raffinose & $1.0 \pm 0.4$ \\
\hline \multirow[t]{2}{*}{ sp. R6x ( $\Delta$ rafR) } & glucose & $0.4 \pm 0.1$ \\
\hline & glucose/raffinose & $34 \pm 8$ \\
\hline \multirow[t]{2}{*}{ sp. R6x ( $\Delta$ rafs) } & glucose & $0.8 \pm 0.1$ \\
\hline & glucose/raffinose & $444 \pm 92$ \\
\hline E. coli & L broth & 0 \\
\hline E. coli pR326aga & L broth & $800 \pm 120$ \\
\hline E. coli rafR/aga & $\mathrm{L}$ broth & $4600 \pm 410$ \\
\hline
\end{tabular}

a(sp.) S. pneumoniae.

bThe activities are expressed in units (nmoles of $p$-nitrophenol produced per min of incubation at room temperature) per mg protein with their S.D. Shown is the mean of three experiments. 


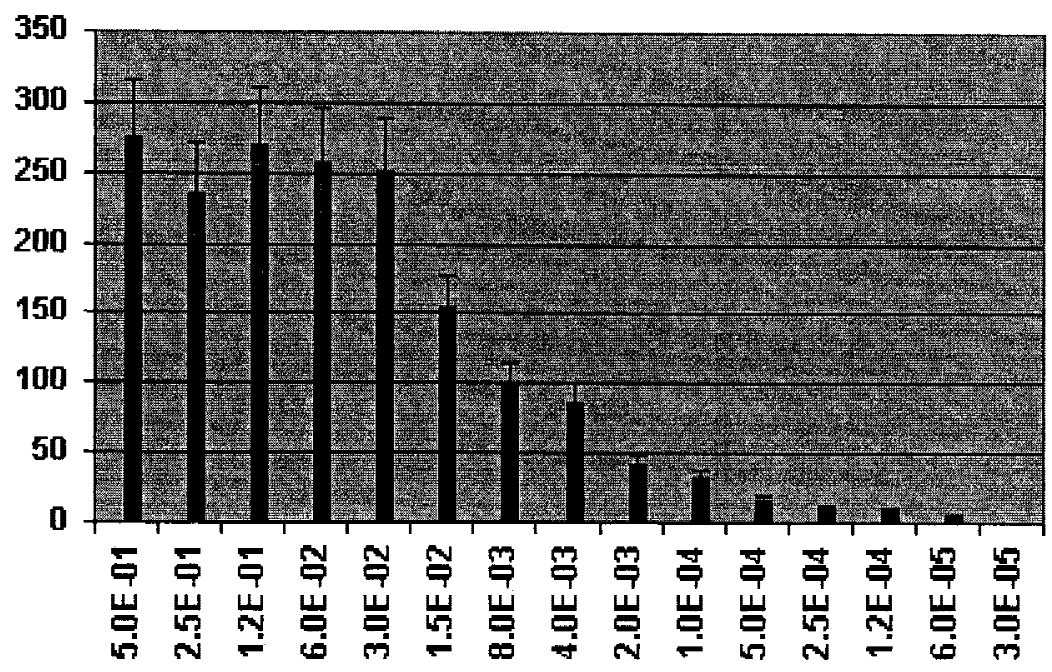

Rafiinose conc. (佔)

Figure $3 \alpha$-Galactosidase activities in the cell lysates of S. pneumoniae strain R6x grown in the presence of $0.2 \%$ glucose and different raffinose concentrations in the growth medium. The activities are expressed in units (nmoles of $p$-nitrophenol produced per min of incubation at room temperature) per $\mathrm{mg}$ protein with their S.D..

maltose, sucrose, and glucose and to induce $\alpha$-galactosidase in the presence of raffinose. Of the six mutant strains, only the $g t f A$ mutant could still ferment raffinose and induce $a g a$ in the presence of raffinose. All the mutants were able to ferment the other sugars, demonstrating that the raf cluster proteins are required for the metabolism of raffinose but not for that of the other sugars tested (Table 2).

Unlike $S$. mutans, $S$. pneumoniae does not ferment melibiose, isomaltose, or isomaltotriose (data not shown). Consistent with this property, none of these sugars serve as inducers of aga expression in $S$. pneumoniae (data not shown).

\section{Catabolite Repression by Sucrose}

To investigate whether the aga promoter is regulated by other mechanisms, pneumococcus strain R6x was

Table 2. Ability of S. pneumoniae Mutants Inactivated in Genes of the raf Cluster to Ferment (Acid Production) Raffinose, other Sugars and to Induce $\alpha$-Galactosidase

\begin{tabular}{lccc}
\hline $\begin{array}{l}\text { Gene } \\
\text { inactivated }\end{array}$ & $\begin{array}{c}\text { Raffinose } \\
\text { fermentation }\end{array}$ & $\begin{array}{c}\text { Sugar } \\
\text { fermentation }^{\mathbf{a}}\end{array}$ & $\begin{array}{c}\boldsymbol{\alpha} \text {-Galactosidase activity } \\
\left(\mathbf{U} / \text { mg protein }^{\mathbf{b}}\right.\end{array}$ \\
\hline none & + & all & $228 \pm 38$ \\
aga & - & all & $0.7 \pm 0.1$ \\
rafE & - & all & $0.9 \pm 0.1$ \\
raff & - & all & $0.8 \pm 0.1$ \\
rafG & - & all & $0.7 \pm 0.1$ \\
gtfA & + & all & $219 \pm 25$ \\
rafX & - & all & $0.7 \pm 0.1$
\end{tabular}

${ }^{a}$ Glucose, fructose, sucrose, galactose, lactose, maltose, inulin, and trehalose.

${ }^{b}$ The $\alpha$-galactosidase activities are expressed in units (nmoles of $p$-nitrophenol produced per min of incubation at room temperature) per $\mathrm{mg}$ protein with their S.D. grown in $\mathrm{C}+\mathrm{Y}+$ raffinose medium supplemented with various other sugars at a final concentration of $0.2 \%$ (see Methods). The resulting $\alpha$-galactosidase activities in the cell lysate were measured (data for sucrose and glucose are shown in Table 1). Only sucrose was able to catabolite-repress aga expression (Table 1). Because sucrose can be transported by the PTS, the ptsII gene of the sucrose-specific PTS was identified in the $S$. pneumoniae genome sequence (www.tigr.com) by homology to the sucrose-specific PTS in B. subtilis. Upon inactivation of the ptsII gene in S. pneumoniae by insertion-duplication mutagenesis, the mutant strain was unable to repress aga induction in the presence of sucrose and raffinose (Table 1 ).

In other Gram-positive bacteria, catabolite repression is mediated through a defined cis-active element (CRE) in the nucleotide sequence of the regulated promoter (Hueck et al. 1994). A 15-bp DNA sequence located $50 \mathrm{bp}$ upstream of the putative aga translation initiation codon (ATG) (Fig. 2A) shows high homology to the CRE consensus sequence (Hueck et al. 1994) and to the CRE sequence identified in the $S$. mutans aga promoter (Simpson and Russell 1998) (Table 3).

In B. subtilis, catabolite repression is mediated by CcpA, a homolog of which was identified within the $S$. pneumoniae genome (www.tigr.com). Insertional inactivation of the $S$. pneumoniae ccpA homolog had no effect on raffinose induction nor sucrose repression of aga expression (Table 1).

\section{Promoter Sequence Analysis of $a g a$}

Translation of the aga gene is most likely initiated from the putative ATG start codon (Fig. 2) that is preceded by a ribosome binding site (TGAGG). Preceding the ribosome binding site was a sequence (TATAA10 and TTTGGAAA-35) that shows similarity to the previously defined pneumococcal promoter consensus sequence (Sabelnikov et al. 1995). Most striking, however, is the pres- 
Table 3. Homology of the CRE Consensus Sequence with the S. pneumoniae CRE Sequence Within the aga Promoter and the $S$. mutans CRE Sequence Within the aga Promoter

\begin{tabular}{ll}
\hline Consensus sequence & TGAAAA CGGTTTCA \\
S. pneumoniae & TGGAAAGCGATTTCA \\
S. mutans & TTAAAA CGGTTACA
\end{tabular}

ence of a direct repeat (ACATTTTACCATATT) at nucleotide positions 21 and 42 (Fig. 2). This repeat motif has high homology to the consensus binding region for $\operatorname{AraC}\left(\mathrm{AGCN}_{7}\right.$ TCCATA) (Gallegos et al. 1997). This potential RafR binding site overlaps the -35 promoter region by $3 \mathrm{bp}$. The cis-active element (CRE) is located following the last repeat and overlaps with the rest of the -35 promoter.

\section{Analysis of mRNA Transcripts}

Putative promoters were assigned upstream of the aga gene, the rafR gene, and the rafE gene (Fig. 2). All promoter sequences show homology to the consensus sequence for $S$. pneumoniae promoters (Sabelnikov et al. 1995). To characterize the mRNA transcripts spanning the raf cluster, reverse transcriptase-PCR (RT-PCR) analysis was performed on total RNA obtained from R6x strain grown in $\mathrm{C}+\mathrm{Y}$ medium supplemented with glucose and raffinose. Figure 4 shows the DNA regions covered by the primers and the results from the RTPCR experiment. A 1.0-kb fragment was amplified using sense and antisense primers within rafR. A 1.5-kb fragment was
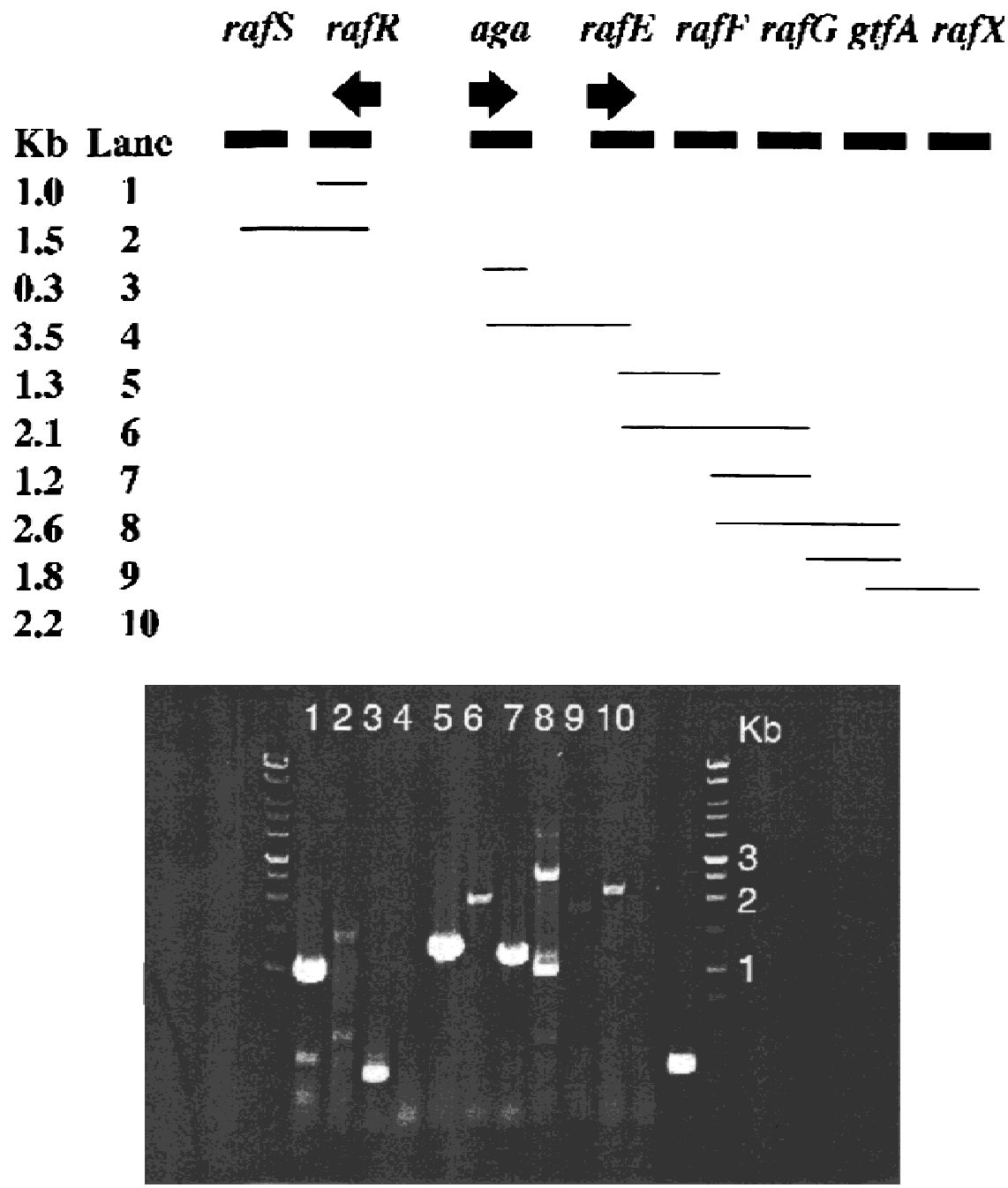

Figure 4 Amplified CDNA from total RNA from the S. pneumoniae strain R6x grown in $\mathrm{C}+\mathrm{Y}$ supplemented with $0.2 \%$ raffinose and $0.2 \%$ glucose. In each reaction (lanes $1-10$ ) one primer pair was used, as indicated by the lines. The expected size for each fragment is given in kb. Lane 11 is a negative control (-) without RT and the primer pair from lane 3 in the reaction mixture; Lane 12 is a positive control $(+)$ with total RNA and primers provided with the Access RT-PCR introductory System. The arrows indicate the identified potential promoters. amplified using the sense primer within rafR and the antisense primer within rafs, confirming that rafR and rafs are cotranscribed, presumably from a promoter upstream of rafR. Primers within the aga gene amplified the expected 0.3-kb DNA fragment. However, primers spanning the aga-rafE genes resulted in no DNA amplification after RT-PCR, indicating that the aga transcript does not extend into rafE and suggesting the presence of an additional promoter between aga and rafE. To investigate how many genes are cotranscribed from the rafE promoter, combinations of primers, each one from a different gene, were generated and tested using the RT-PCR approach. All different primer combinations amplified a DNA fragment of the predicted size (Fig. 4). The additional cDNA bands in the RT-PCR reactions presumably reflect nonspecific binding of the oligonucleotides to other gene sequences or additional internal promoters.

\section{DISCUSSION}

A gene cluster responsible for utilization of raffinose was identified in S. pneumoniae and named the raf cluster. The sequence of $\sim 10,200$ bp contains eight open reading frames, which were named rafs, rafR, aga, rafE, rafF, rafG, gtfA, and rafX to indicate 
their role in raffinose utilization. Because most of the proteins are homolog to the proteins of the $S$. mutans multiple sugar metabolism ( $\mathrm{msm}$ ) system, we have named the pneumococcal components according to the $S$. mutans nomenclature (Russell et al. 1992). Raffinose was identified as the inducer for aga when added to the growth medium. The extent of induction in the presence of raffinose is 500-fold based on increased $\alpha$-galactosidase activity. The mechanism of regulation by raffinose and the identity of the actual trigger for induction remain unknown. The level of aga induction depends on the raffinose concentration in the medium, which results in a raffinose titratable promoter system with different levels of gene expression, which could be a useful tool for regulated gene expression in S. pneumoniae.

Based on the homology, the raf cluster contains all the genes needed for the early steps of raffinose metabolism. Aga is the $\alpha$-galactosidase that cleaves raffinose into galactose and sucrose. Sucrose might be subsequently hydrolyzed and phosphorylated by GtfA (sucrose phosphorylase), which is a bifunctional enzyme to yield fructose and glucose-1-phosphate for further metabolism (Russell et al. 1988). Inactivation of $g t f A$ in the raf cluster was unique in that it had no effect on the phenotype in regards to raffinose metabolism or aga induction. Apparently, the mutation in $g t f A$ was not polar on rafX, and GtfA is not required for raffinose metabolism. Structural and functional analysis indicates that RafS is a repressor of the aga promoter. In contrast, the decreased $\alpha$-galactosidase activity in the rafR mutant suggests that RafR is an activator of aga expression. This is in agreement with the homology of RafR to members of the AraC/XylS family of transcriptional regulators. The remaining $\alpha$-galactosidase activity $(34 \mathrm{U} / \mathrm{mg}$ protein in the mutant vs. $200 \mathrm{U} / \mathrm{mg}$ protein in wild type) in the rafR mutant could reflect basal level promoter activity.

Based on homology studies and insertional inactivation of the remaining genes (rafE, rafF, rafG, and raf $X$ ) in the raf cluster, the corresponding proteins are involved in utilization of raffinose. The results from the gene inactivation experiments could indicate a polar effect from rafE on rafF or rafG; it will be necessary to construct nonpolar mutations to draw conclusions on the role of RafF and RafG in raffinose utilization. However, the strong homology of RafE, RafF, and RafG to other sugar transport proteins suggests that these proteins are involved in raffinose transport. Despite the similarities between the raf and msm gene clusters, the products of raf genes are involved in the metabolism of raffinose alone. In contrast, the products of the $m s m$ genes are involved in uptake of raffinose, melibiose, and isomaltotriose and metabolism of melibiose, sucrose, and isomaltosaccharides (Russell et al. 1992). This difference could be due to the absence of ho- mologs of $m s m K$ or dexB in the raf cluster or differences in substrate specificity of the metabolic enzymes or transport systems.

Three promoters were ascribed in the gene cluster using sequence analysis and RT-PCR on total RNA. One transcript was found for the rafR and rafS genes, suggesting a mutual promoter for these genes. The gene products from rafR and rafS regulate the aga promoter, which is transcribed in the opposite direction. The inverted repeat identified within the aga promoter shows high homology to the AraC binding region (Gallegos et al. 1997) and could function as the binding region for the activator RafR. This repeat was shown to be essential for activation of the promoter $\mathrm{P}_{\mathrm{araBAD}}$ in E. coli, which also overlaps the -35 promoter region by $4 \mathrm{bp}$.

Consistent with a putative third promoter sequence upstream of rafE, RT-PCR experiments showed that the remaining genes (rafE, rafF, rafG, gtfA, and raf $X$ ) are likely to be organized in an operon transcribed from a proximal promoter. However, the presence of internal promoters cannot be excluded.

Protein sequence analysis of the RafE protein sequence revealed a putative signal sequence with homology to a lipid anchor sequence at the cleavage region. The identified ATP/GTP and solute binding motifs are close to the amino-terminal end of the protein and might be exposed to the extracellular site of the bacteria, because an identified lipid-anchor motif at the amino-terminal end of RafE suggests that this protein is anchored in the membrane. Members of the solute binding motif's family are known to be bound to the membrane via an amino-terminal lipid anchor and probably serve as receptors to trigger or initiate translocation of the solute (Tam and Saier 1993), in this case the transport of raffinose.

The RGD motif was first identified in extracellular matrix proteins, where it is crucial for their interaction with integrin, a cell surface receptor (Ruoslahti and Pierschbacher 1986). The RGD sequence was subsequently characterized as a putative cell-binding sequence and has been shown to promote eukaryotic cell attachment (d'Souza et al. 1991). Whether the tripeptide Arg-Gly-Asp (RGD) found within the RafE sequence is involved in cell attachment of $S$. pneumoniae is unclear, and further experiments are necessary. However, the connection of sugar metabolism and the expression of virulence factors has been established in several pathogenic bacteria (Martinez-Cadena et al. 1981; Smith et al. 1986; Busque et al. 1995; Milenbachs et al. 1997), and it may provide an advantage to colonize a niche in the host.

Because the PTS is the preferred sugar transport system in bacteria, other non-PTS transport systems can be regulated by PTS-mediated catabolite repression. In the presence of sucrose in the medium, no aga 
induction was detected, whereas none of the other sugars tested, including glucose, showed repression of aga induction. This is highly unusual, because most of the catabolite repression in prokaryotes is mediated by glucose and not sucrose in the medium (Saier et al. 1996). To further investigate the catabolite repression mechanism, the enzyme II (ptsII) of the sucrose-specific PTS was inactivated. The ptsII mutant lost its ability to repress the aga promoter in the presence of sucrose. This observation supports the theory that the sucrosespecific PTS is either directly or indirectly involved in the regulation of raffinose utilization. This suggests that $S$. pneumoniae uses the PTS as the preferred sugar transport system, with sucrose being most likely the preferred carbon source among the sugars tested.

Upstream of the translation initiation codon for aga, a highly homologous sequence to the cis-active element (CRE) consensus sequence was identified. Because catabolite repression in B. subtilis (Miwa et al. 1994), B. Megaterium (Deutscher et al. 1995), Staphylococcus xylosus (Egeter and Brückner 1996), and Lactococcus lactis (Luesink et al. 1998) is mediated by the protein CcpA, it has been hypothesized that this protein is a common mediator between the PTS and the regulated gene in Gram-positive bacteria (Hueck et al. 1994; Saier et al. 1996; Luesink et al. 1998). A homolog of the B. subtilis CcpA protein was identified in the $S$. pneumoniae genome, but inactivation of the gene had no effect on the regulation of aga expression. Because a mutation in a CcpA homolog in S. mutans (Simpson and Russell 1998) showed the same phenotype, the regulation of catabolite repression in Streptococcus seems to be either mediated through PTS directly or a, so far, unidentified regulatory protein.

\section{METHODS}

\section{Strains and Media}

The nonvirulent $S$. pneumoniae strain R6x (Tiraby and Fox 1973) was used for the experiments. S. pneumoniae strains were routinely plated on tryptic soy agar supplemented with sheep blood (TSAB) to a final concentration of $3 \%$ (vol/vol). Cultures were grown in a liquid semisynthetic casein hydrolysate medium supplemented with yeast extract but without any carbon source (C+Y medium) (Lacks and Hotchkiss 1960). The carbon source was added to a final concentration of $0.2 \%$ (wt/vol) if not otherwise indicated. Mutants harboring vector pR326 were grown in the presence of $2.5 \mu \mathrm{g} / \mathrm{ml}$ chloramphenicol. E. coli strain JM109 (Promega, Madison, WI) was used for cloning experiments and grown in L broth-based medium with aeration at $37^{\circ} \mathrm{C}$. Recombinant E. coli strains carrying vector $\mathrm{pR} 326$ were grown in the presence of $25 \mu \mathrm{g} / \mathrm{ml}$ chloramphenicol.

\section{DNA Techniques and Sequence Analysis}

DNA techniques, including plasmid preparations, restriction endonuclease digestion, ligations, PCR, and genetic manipulation of $E$. coli, were performed according to standard protocols (Maniatis 1989) and the specifications of the manufac- turers. Chromosomal DNA of $S$. pneumoniae was isolated as described previously (Pearce et al. 1993). The raf cluster was identified by searching the $S$. pneumoniae genome database (at www.tigr.com), accessible from the National Center for Biotechnology Information (NCBI) Web page (http:// www.ncbi.nlm.nih.gov/BLAST/), with AraC from E. coli as the query sequence. The gene region starting at $r a f S$ and including rafR, aga, and rafE was PCR-amplified using Pfu turbo (Stratagene, La Jolla, CA) and sequenced. DNA sequencing was done at Sequatech (Mountain View, CA). Protein and DNA sequences were analyzed with the GCG Wisconsin package (GCG, Madison, WI).

\section{Insertion-Duplication Mutagenesis in S. pneumoniae}

An internal DNA fragment of the target gene was PCRamplified and ligated into the T-tailed (Marchuk et al. 1991) vector pR326 (Claverys et al. 1995), which replicates in E. coli but not $S$. pneumoniae. After transformation into E. coli JM109, a single transformant that contained the vector with the DNA fragment was identified. Plasmid DNA from this clone was transformed into $S$. pneumoniae strain R6x as described previously (Pearce et al. 1993). Transformants were selected on TSAB plates containing chloramphenicol $(2.5 \mu \mathrm{g} / \mathrm{ml})$. PCR analysis of the mutant's chromosomal DNA was used to confirm homologous recombination of the cloned internal fragment into the target gene.

\section{Expression of $a g a$ and rafR in E. coli}

The aga gene including the promoter region was amplified by PCR on chromosomal DNA from pneumococcus R6x using the following primers: sense, 5'-GCGCCGGAATTCCATGTGCTACCTCCTACCTAACATTTTACC-3' and antisense, 5' CGCGGATCCTCATAGTTTTCTAAAAATATAC-3'. The amplified 2-kb fragment includes the ribosomal binding site, the -10 and -35 promoter elements, and an additional 70-bp upstream sequence. The PCR product was cloned in pR326 (Claverys et al. 1995) using the BamHI and EcoRI restriction sites. After transformation in E. coli JM109, colonies were tested for $\alpha$-galactosidase activity and showed high $\alpha$-galactosidase expression. The rafR gene was PCR-amplified using the sense primer 5'-GGCCCTTCCATATGCATTTACTTCACCTCATCACTTTATTG-3' and the antisense primer $5^{\prime}$-CCCGGAATTCAGCTTGGTAGGATTTCATAATGTTGCC-3'. The PCR product was cloned in the T-tailed vector pGEMT-Easy (Promega, Madison, WI) and transformed into the E. coli strain expressing pneumococcal $\alpha$-galactosidase. From the strain $E$. coli aga/RafR, the $\alpha$-galactosidase activity was measured.

\section{RNA Analysis}

Total RNA was isolated from $S$. pneumoniae strain R6x grown in $\mathrm{C}+\mathrm{Y}$ medium containing $0.2 \%$ glucose and $0.2 \%$ raffinose using RNAeasy mini kit (Qiagen, Santa Clarita, CA) according to the recommended procedure, except that cell lysis was performed using $0.25 \%$ Triton X-100 in TE buffer for 10 min at $37^{\circ} \mathrm{C}$. After resuspension in DEPC-treated water, RNA was treated with RQ1 RNase free DNase (Promega, Madison, WI). The isolated RNA was used in RT-PCR reactions using Access RT-PCR Introductory System (Promega, Madison, WI). The reaction was performed using $1 \mu \mathrm{g}$ of total RNA, $1 \mu \mathrm{M}$ sense primer, $1 \mu \mathrm{M}$ antisense primer, $1 \times \mathrm{AMV} / \mathrm{Tfl}$ reaction buffer, $0.2 \mathrm{~mm}$ dNTP mix, $1 \mathrm{mM} \mathrm{MgSO}_{4}, 0.1 \mathrm{U} / \mu \mathrm{l}$ AMV reverse transcriptase, $0.1 \mathrm{U} / \mu \mathrm{l}$ Tfl DNA polymerase, and nuclease-free water to a final volume of $50 \mu$ l. The RT reaction was performed 
at $48^{\circ} \mathrm{C}$ for $45 \mathrm{~min}$; an initial denaturation was performed at $94^{\circ} \mathrm{C}$ for $2 \mathrm{~min}$, followed by 40 cycles at $94^{\circ} \mathrm{C}$ for $30 \mathrm{sec}, 52^{\circ} \mathrm{C}$ for $1 \mathrm{~min}$, and at $68^{\circ} \mathrm{C}$ for $2 \mathrm{~min}$. An additional extension was performed at $68^{\circ} \mathrm{C}$ for $7 \mathrm{~min}$. The RT-PCR products obtained were loaded on an $0.7 \%$ agarose gel for analysis.

\section{Sugar Utilization Assay}

S. pneumoniae strain R6x and mutant strains obtained by insertion-duplication mutagenesis in individual genes in the raf cluster were grown in $1.5 \mathrm{ml}$ of $\mathrm{C}+\mathrm{Y}$ medium supplemented with glucose and chloramphenicol for the mutants, to an optical density $\left(\mathrm{OD}_{600}\right)$ of 0.5 . Cells were harvested by centrifugation, washed twice with $\mathrm{C}+\mathrm{Y}$ medium containing no sugars, and resuspended in $1 \mathrm{ml}$ of the same medium. This inoculum was diluted 1:300 in $5 \mathrm{ml}$ of $\mathrm{C}+\mathrm{Y}$ medium containing chloramphenicol $(2.5 \mu \mathrm{g} / \mathrm{ml})$ when needed, and $0.2 \%$ (wt $/ \mathrm{vol})$ of the following sugars was tested: glucose, sucrose, raffinose, inulin, galactose, maltose, lactose, fructose, and trehalose. Phenol red solution was added to each tube to a final concentration of $0.02 \%(\mathrm{vol} / \mathrm{vol})$ and incubated at $37^{\circ} \mathrm{C}$ for $4 \mathrm{hr}$. Sugar utilization by the bacteria results in acid production changing the color of the medium from red to yellow. A control culture without sugar added was included in each experiment. All assays were made in duplicates.

\section{$\alpha$-Galactosidase Enzyme Assay}

S. pneumoniae strains were grown to an $\mathrm{OD}_{600}$ of $0.5 \mathrm{in} 3 \mathrm{ml}$ of $\mathrm{C}+\mathrm{Y}$ medium containing the test sugar. A $200-\mu \mathrm{l}$ aliquot was pelleted by centrifugation, and cells were resuspended in 100 $\mu$ l of sodium phosphate buffer $(\mathrm{pH} 7.5)$ containing $0.25 \%$ Triton X-100 and incubated at $37^{\circ} \mathrm{C}$ for $10 \mathrm{~min}$. Ten microliters of the cell lysate was used for protein quantification using the BCA Protein Assay Kit (Pierce, Rockford, Il). To measure $\alpha$-galactosidase activity, $10 \mu \mathrm{l}$ of the cell lysate was incubated with $90 \mu \mathrm{l}$ of the substrate solution $\left[1 \mathrm{~mm} \mathrm{MgCl}_{2}, 4.5 \mathrm{~mm}\right.$ $\beta$-mercaptoethanol, $90 \mu \mathrm{g} p$-nitrophenyl- $\alpha$-D-galactopyranoside (Sigma, St. Louis, MO) in 0.1 M sodium phosphate buffer at $\mathrm{pH}$ 7.5] for $5 \mathrm{~min}$ at room temperature. When using $E$. coli, cells were disintegrated by ultrasonication, and cell debris were removed by centrifugation. $\alpha$-Galactosidase activity was followed by measuring absorption $(405 \mathrm{~nm})$ of the product $p$-nitrophenol. A standard curve was obtained using p-nitrophenol at 800, 600, 400, 200, 100, and $0 \mu \mathrm{M}$. Units of $\alpha$-galactosidase were defined as nmoles of $p$-nitrophenol per minute.

\section{ACKNOWLEDGMENTS}

Sequence data were obtained from the TIGR web site at http:// www.tigr.org. We thank D.A. Morrison for providing the integration vector pR326 and P. Margolis for critical reading of the manuscript.

The publication costs of this article were defrayed in part by payment of page charges. This article must therefore be hereby marked "advertisement" in accordance with 18 USC section 1734 solely to indicate this fact.

\section{REFERENCES}

Bower, S., J. Perkins, R.R. Yocum, P. Serror, A. Sorokin, P. Rahaim, C.L. Howitt, N. Prasad, S.D. Ehrlich, and J. Pero. 1995. Cloning and characterization of the Bacillus subtilis birA gene encoding a repressor of the biotin operon. J. Bacteriol. 177: 2572-2575.

Busque, P., A. Letellier, J. Harel, and J.D. Dubreuil. 1995. Production of Escherichia coli STb enterotoxin is subject to catabolite repression. Microbiology 141: 1621-1627.
Claverys, J.P., A. Dintilhac, E.V. Pestova, B. Martin, and D.A. Morrison. 1995. Construction and evaluation of new drug-resistance cassettes for gene disruption mutagenesis in Streptococcus pneumoniae, using an ami test platform. Gene 164: $123-128$.

Cvitkovitch, D.C., D.A. Boyd, and I.R. Hamilton. 1995. Regulation of sugar transport via the multiple sugar metabolism operon of Streptococcus mutans by the phosphoenolpyruvate phosphotransferase system. J. Bacteriol. 177: 5704-5706.

Deutscher, J., E. Küster, U. Bergstedt, V. Charrier, and W. Hillen. 1995. Protein kinase-dependent HPr/CcpA interaction links glycolitic activity to carbon catabolite repression in Gram-positive bacteria. Mol. Microbiol. 15: 1049-1053.

d'Souza, S.E., M.H. Ginsberg, and E.F. Plow. 1991. Arginyl-glycyl-aspartic acid (RGD): A cell adhesion motif. Trends Biochem. Sci. 16: 246-250.

Egeter, O. and R. Brückner. 1996. Catabolite repression mediated by the catabolite control protein CcpA in Staphylococcus xylosus. Mol. Microbiol. 21: 739-749.

Gallegos, M.-T., R. Schleif, A. Bairoch, K. Hofmann, and J.L. Ramos. 1997. AraC/XylS family of transcriptional regulators. Microbiol. Mol. Biol. Rev. 61: 393-410.

Higgins, C.F., S.C. Hyde, M.M. Mimmack, U. Gileadi, D.R. Gill, and M.P. Gallagher. 1990. Binding protein-dependent transport systems. J. Bioenerg. Biomembr. 22: 571-592.

Holt, J., N.R. Krieg, P.H.A. Sneath, J.T.A. Staley, and S.T. Williams. 1994. Bergey's manual of determinative bacteriology. Williams \& Wilkins, Baltimore, MD.

Hueck, C.J., W. Hillen, and J.M.H. Saier. 1994. Analysis of a cis-active sequence mediating catabolite repression in Gram-positive bacteria. Res. Microbiol. 145: 503-518.

Lacks, S. and R.D. Hotchkiss. 1960. A study of the genetic material determining an enzyme activity in pneumococcus. Biochim. Biophys. Acta 39: 508-517.

Luesink, E.J., R.E. van Herpen, O.P. Kuipers, and W.M. de Vos. 1998. Transcriptional activation of the glycolytic las operon and catabolite repression of the gal operon in Lactococcus lactis are mediated by the catabolite control protein CcpA. Mol. Microbiol. 30: 789-798.

Maniatis, T., E.F. Fritsch, and J. Sambrook. 1989. Molecular cloning: A laboratory manual. Cold Spring Harbor Laboratory, Cold Spring Harbor, NY.

Marchuk, D., M. Drumm, A. Saulino, and F.S. Collins. 1991. Construction of T-vectors, a rapid and general system for direct cloning of unmodified PCR products. Nucleic Acids Res. 19: 1154.

Martinez-Cadena, M.G., L.M. Guzman-Verduzco, H. Stieglitz, and Y.M. Kupersztoch-Portnoy. 1981. Catabolite repression of Escherichia coli heat stable enterotoxin activity. J. Bacteriol. 145: $722-728$.

Milenbachs, A.A., D.P. Brown, M. Moors, and P. Youngman. 1997. Carbon source regulation of virulence gene expression in Listeria monocytogenes. Mol. Microbiol. 23: 1075-1085.

Miwa, Y., M. Saikawa, and Y. Fujita. 1994. Possible function and some properties of the CcpA protein in Bacillus subtilis. Microbiology 140: 2567-2575.

Nieto, C., M. Espinosa, and A. Puyet. 1997. The maltose/maltodextrin regulon of Streptococcus pneumoniae. J. Biol. Chem. 272: 30860-30865.

Pearce, B.J., Y.B. Yin, and H.R. Masure. 1993. Genetic identification of exported proteins in Streptococcus pneumoniae. Mol. Microbiol. 9: $1037-1050$.

Postma, P.W. and J.W. Lengeler. 1985. Phosphoenolpyruvate:carbohydrate phosphotransferase system of bacteria. Microbiol. Rev. 49: 232-269.

Postma, P.W., J.W.A. Lengeler, and G.R. Jacobson. 1993. Phosphoenolpyruvate:carbohydrate phosphotransferase system of bacteria. Microbiol. Rev. 57: 543-594.

Ruoslahti, E. and M.D. Pierschbacher. 1986. Arg-Gly-Asp: A versatile cell recognition signal. Cell 44: 517-518.

. 1987. New perspective in cell adhesion: RGD and integrins. Science 238: 491-497.

Russell, R.R., H. Mukasa, A. Shimamura, and J.J. Ferretti. 1988. 
Streptococcus mutans gtfA gene specifies sucrose phosphorylase. Infect. Immun. 56: 2763-2765.

Russell, R.R., J. Aduse-Opoku, I.C. Sutcliffe, L. Tao, and J.J. Ferretti. 1992. A binding protein-dependent transport system in Streptococcus mutans responsible for multiple sugar metabolism. J. Biol. Chem. 267: 4631-4637.

Sabelnikov, A.G., B. Greenberg, and S.A. Lacks. 1995. An extended -10 promoter alone directs transcription of the DpnII operon of Streptococcus pneumoniae. J. Mol. Biol. 250: 144-155.

Saier, M.H. 1996. Cyclic AMP-independent catabolite repression in bacteria. FEMS Microbiol. Lett. 138: 97-103.

Saier, M.H.J., S. Chauvaux, G.M. Cook, J. Deutscher, I.T. Paulsen, J. Reizer, and J.-J. Ye. 1996. Catabolite repression and inducer control in Gram-positive bacteria. Microbiology 142: 217-230.

Simpson, C.L. and R.R.B. Russell. 1998. Identification of a homolog of CcpA catabolite repressor protein in Streptococcus mutans. Infect. Immun. 66: 2085-2092.

Smith, J.L., M.M. Bencivengo, and C.A. Kunsch. 1986. Enterotoxin a synthesis in Staphylococcus aureus: Inhibition by glycerol and maltose. J. Gen. Microbiol. 132: 3375-3380.

Stassi, D.L., J.J. Dunn, and S.A. Lacks. 1982. Nucleotide sequence of DNA controlling expression of genes for maltosaccharide utilization in Streptococcus pneumoniae. Gene 20: 359-366.

Tam, R. and M.H.J. Saier. 1993. Structural, functional, and evolutionary relationships among extracellular solute-binding receptors of bacteria. Microbiol. Rev. 57: 320-346.

Tiraby, G. and M.S. Fox. 1973. Marker discrimination in transformation and mutation of pneumococcus. Proc. Natl. Acad. Sci. 70: $3541-3545$.

Vadeboncoeur, C. and M. Pelletier. 1997. The phosphoenolpyruvate: sugar phosphotransferase system of oral streptococci and its role in the control of sugar metabolism. FEMS Microbiol. Rev. 19: 187-207. von Heijne, G. 1998. The structure of signal peptides from bacterial lipoproteins. Protein Eng. 2: 531-534.

Received June 30, 1999; accepted in revised form October 18, 1999. 


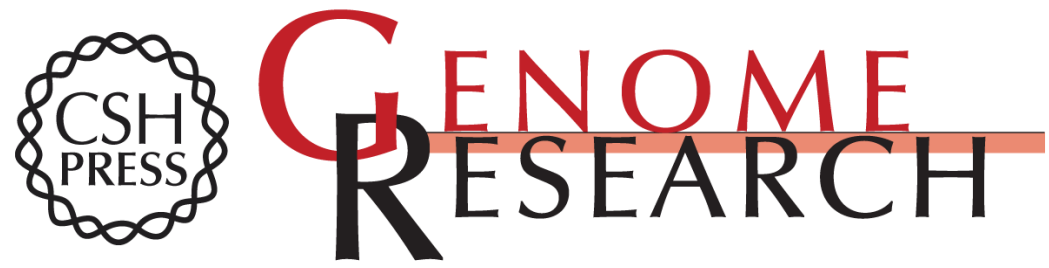

\section{Regulation of the $\alpha$-Galactosidase Activity in Streptococcus pneumoniae : Characterization of the Raffinose Utilization System}

Carsten Rosenow, Mita Maniar and Joaquim Trias

Genome Res. 1999 9: 1189-1197

Access the most recent version at doi:10.1101/gr.9.12.1189

References This article cites 34 articles, 13 of which can be accessed free at: http://genome.cshlp.org/content/9/12/1189.full.html\#ref-list-1

\section{License}

Email Alerting Receive free email alerts when new articles cite this article - sign up in the box at the Service top right corner of the article or click here.

\section{Affordable, Accurate Sequencing.}

